\title{
Pulmonary hypertension in lymphangioleiomyomatosis: characteristics in 20 patients
}

\begin{abstract}
Vincent Cottin, Sergio Harari, Marc Humbert, Hervé Mal, Peter Dorfmüller, Xavier Jaïs, Martine Reynaud-Gaubert, Grégoire Prevot, Romain Lazor, Camille Taillé, Jacques Lacronique, Sabrina Zeghmar, Gérald Simonneau, Jean-François Cordier and the Groupe d'Etudes et de Recherche sur les Maladies "Orphelines" Pulmonaires (GERM"O"P)
\end{abstract}

ABSTRACT: This retrospective, multicentre study evaluated patients with lymphangioleiomyomatosis (LAM) and pre-capillary pulmonary hypertension ( $\mathrm{PH}$ ) by right heart catheterisation.

It was conducted in 20 females with a mean \pm SD age of $49 \pm 12$ yrs and a mean \pm SD time interval between LAM and PH diagnoses of $9.2 \pm 9.8 \mathrm{yrs}$. All, except for one patient, were receiving supplemental oxygen. 6-min walking distance was mean \pm SD $340 \pm 84$ m. Haemodynamic characteristics were: mean pulmonary artery pressure (PAP) $32 \pm 6 \mathrm{mmHg}$, cardiac index $3.5 \pm 1.1 \mathrm{~L} \cdot \mathrm{min}^{-1} \cdot \mathrm{m}^{-2}$ and pulmonary vascular resistance (PVR) $376 \pm 184 \mathrm{dyn} \cdot \mathrm{s} \cdot \mathrm{cm}^{-5}$. Mean PAP was $>35 \mathrm{mmHg}$ in only $20 \%$ of cases. The forced expiratory volume in $1 \mathrm{~s}$ was $42 \pm 25 \%$, carbon monoxide transfer factor was $29 \pm 13 \%$, and arterial oxygen tension $\left(\mathrm{Pa}, \mathrm{O}_{2}\right)$ was $7.4 \pm 1.3 \mathrm{kPa}$ in room air. Mean PAP and PVR did not correlate with $\mathrm{Pa}_{1} \mathrm{O}_{2}$. In six patients who received oral pulmonary arterial hypertension (PAH) therapy, the PAP decreased from $33 \pm 9 \mathrm{mmHg}$ to $24 \pm 10 \mathrm{mmHg}$ and the PVR decreased from $481 \pm 188 \mathrm{dyn} \cdot \mathrm{s} \cdot \mathrm{cm}^{-5}$ to $280 \pm 79 \mathrm{dyn} \cdot \mathrm{s} \cdot \mathrm{cm}^{-5}$. The overall probability of survival was $94 \%$ at $2 \mathrm{yrs}$.

Pre-capillary PH of mild haemodynamic severity may occur in patients with LAM, even with mild pulmonary function impairment. PAH therapy might improve the haemodynamics in $\mathrm{PH}$ associated with LAM.

KEYWORDS: Interstitial lung disease, lymphangioleiomyomatosis, pulmonary hypertension

ymphangioleiomyomatosis (LAM), a disease that mostly affects young and middleaged females [1-3], is characterised by the proliferation of abnormal smooth muscle-like cells (so-called LAM cells) along lymphatics in the lungs and abdomen. Manifestations of LAM include: diffuse cystic lung disease; recurrent pneumothoraces; benign renal tumours (e.g. angiomyolipomas); and lymphatic abnormalities, which include pleural and peritoneal chylous effusion as well as abdominal lymphangioleiomyomas. Pulmonary involvement is dominated by the formation and progression of thin-walled cysts, the pathogenesis of which may implicate metalloprotease secretion by LAM cells, leading to airflow obstruction, impairment of carbon monoxide diffusion capacity, and chronic respiratory insufficiency [1-4]. Although sirolimus (a mammalian target of rapamycin (mTOR) inhibitor) has recently been demonstrated to slow the rate of lung function decline [5], lung transplantation is the sole treatment for LAM patients with advanced disease [6-9]. Kaplan-Meier analysis estimated transplantation-free survival to be $\sim 80-90 \%$ at $10 \mathrm{yrs}$ in a recent series of LAM patients [10,11]. However, the rate of disease progression is highly variable among patients [12-15].

Pulmonary hypertension $(\mathrm{PH})$, which may occur in LAM patients [16], is included in the $\mathrm{PH}$ group with unclear and/or multifactorial mechanisms in the Dana Point clinical classification of PH (group 5) [17]. Likely multifactorial [18] $\mathrm{PH}$ pathogenesis in LAM patients is related, at least in part, to hypoxia and reduced pulmonary vascular capacitance caused by cystic lesions [19]. In addition, mTOR expression is up-regulated in LAM [20], and activation of mTOR complexes 1 and 2 is
AFFILIATIONS

For a full list of affiliations, please see the Acknowledgements section.

CORRESPONDENCE

J-F. Cordier

Hôpital Louis Pradel

69677 Lyon (Bron) Cedex

France

E-mail: jean-francois.cordier

@chu-lyon.fr

Received:

June 012011

Accepted after revision:

Dec 072011

First published online:

Feb 232012 
further enhanced by hypoxia, contributing to smooth muscle cell proliferation [21] and conceivably to $\mathrm{PH}$ pathogenesis. TAVEIRADASILVA et al. [19] reported 7\% PH prevalence in 95 patients with LAM, as defined by estimated systolic pulmonary artery pressure (PAP) $>35 \mathrm{mmHg}$ on echocardiography. $\mathrm{PH}$, confirmed by right heart catheterisation (RHC) (mean PAP > $25 \mathrm{mmHg}$ ), was diagnosed in nine $(45 \%)$ out of the 20 patients evaluated for lung transplantation [7]. Little information is available regarding the haemodynamic profile of PH in LAM, and there are no data on the effect of pulmonary arterial hypertension (PAH)-specific therapy, such as endothelin receptor antagonists, phosphodiesterase type- 5 inhibitors and prostacyclin derivatives.

This study aimed to: 1) evaluate by RHC the haemodynamic characteristics of patients with LAM and $\mathrm{PH}$ not explained otherwise; 2) determine whether haemodynamics may be related to pulmonary function; 3) ascertain the survival of $\mathrm{PH}$ patients with LAM; and 4) explore whether $\mathrm{PH}$-specific therapy, given off-label on an individual basis, can bring about significant clinical and/or haemodynamic improvements.

\section{PATIENTS AND METHODS}

\section{Study design}

This multicentre study was undertaken by the French Reference Centre for Rare Pulmonary Diseases (Lyon, France; coordinator J-F. Cordier), the French Reference Centre for Pulmonary Hypertension (Clamart, France; coordinator G. Simonneau), the Centre for Rare Pulmonary Diseases (Milan, Italy; coordinator S Harari), the Network of French Competence Centres for Rare Pulmonary Diseases (Lyon, France; coordinator J-F. Cordier) and Competence Centres for Pulmonary Hypertension (Clamart, France; coordinator G. Simonneau), and the Groupe d'Etudes et de Recherche sur les Maladies "Orphelines" Pulmonaires (GERM"O"P), a collaborative group dedicated to research on rare (so-called "orphan") pulmonary diseases. Participating physicians prospectively reported all cases of LAM to the GERM"O"P registry (coordinator J-F. Cordier). PH was screened by echocardiography at the discretion of the physicians; however, most groups in France and Italy perform echocardiography once a year in LAM patients with impaired lung function. RHC was implemented in cases of suspected $\mathrm{PH}$ (with estimated systolic PAP of $\geqslant 40 \mathrm{mmHg}$ on echocardiography) or evaluation for lung transplantation.

Data on PH were collected prospectively from the Registry of the French Network of Pulmonary Hypertension that now comprises of 24 university pulmonary vascular centres [22]. The registry was opened in 2002 and enrolled all consecutive patients aged $\geqslant 18$ yrs with pre-capillary $\mathrm{PH}$ seen at these centres. Additional results on LAM were obtained, retrospectively, and data collection ended in December 2010. A control group of patients with LAM (without $\mathrm{PH}$ ) was obtained from the active file of the centres. This study was compliant with the requirements of the Commission nationale de l'informatique et des libertés (Paris, France) the organisation dedicated to privacy, information technology, and civil rights in France. All patients provided informed consent before participation [22]. The study was approved by the Institutional Review Board of the French Learned Society for Respiratory Medicine and registered at www.clinicaltrials.gov (NCT00960895).

\section{Inclusion criteria}

The following inclusion criteria applied: 1) Definite or probable LAM diagnosed according to European Respiratory Society (ERS) recommendations [6]. 2) Pre-capillary PH, defined by mean $\mathrm{PAP} \geqslant 25 \mathrm{mmHg}$ and pulmonary artery wedge pressure $\leqslant 15 \mathrm{mmHg}$ at RHC [23].

Patients with PAH, either idiopathic, heritable, or associated with connective tissue diseases related to portal hypertension, congenital heart disease, human immunodeficiency virus infection, or $\mathrm{PH}$ due to left heart disease or chronic thromboembolic $\mathrm{PH}$, were excluded. Chronic thromboembolic $\mathrm{PH}$ was ruled out by ventilation perfusion scanning and high resolution computed tomography (HRCT) of the chest. "Out-of-proportion" precapillary $\mathrm{PH}$ was defined by mean PAP $>35-40 \mathrm{mmHg}$.

\section{Investigations}

RHC was performed as described elsewhere [24] with values obtained at end of expiration. Cardiac output was measured by the standard thermodilution technique. A vasodilator test with inhaled nitric oxide (10 ppm for 5-10 min) was carried out, and positive acute responses were defined as a decrease in mean PAP of $>10 \mathrm{mmHg}$ compared with baseline mean PAP (with mean PAP $<40 \mathrm{mmHg}$ ), and normal or increased cardiac output [24].

Pulmonary function tests followed the joint guidelines of the American Thoracic Society and the ERS [25-27]. Lung volume was measured by whole-body plethysmography (Jaeger Masterscreen Body®; Sebbac, Wuerzburg, Germany), and data were expressed as percentages of predicted values [28]. A nonencouraged 6-min walk test (6MWT) was performed according to recommendations [29].

The date of PH diagnosis was defined as the date of RHC, and all data (symptoms including New York Heart Association (NYHA) functional class, 6MWT, pulmonary function, echocardiography) were obtained within 2 months of RHC. PH treatment was left to the physicians' discretion, including the management of pleural and other LAM manifestations, oxygen supplementation as needed, oral anticoagulation, diuretics, and possible PAH-specific therapy initiated after RHC.

\section{Pathology}

Explanted lungs of transplanted patients were reviewed by a pathologist with particular expertise in pulmonary vascular disease. The presence of LAM/perivascular epithelioid cells (PEComa cells) was semi quantified as absent, mild, moderate, or high, along cyst edges, alveolar walls, bronchioles, pulmonary arteries, veins and lymphatics. Cells within the remodelled pulmonary arteries were further characterised by HMB45 immunostaining.

\section{Statistical analysis}

The data were analysed by Microsoft Excel 2003 and SPSS 17.0 (SSPS Inc., Chicago, IL, USA). All values were expressed as mean \pm SD. Correlations were calculated with Pearson's correlation coefficient. The probability of survival at each time-point was estimated according to the Kaplan-Meier method, from the date of the first haemodynamic evaluation demonstrating $\mathrm{PH}$ to the end-point of death or censoring. All-cause mortality was included in survival statistics. For overall survival calculation, transplanted subjects were censored at the time of transplantation. Living 
patients were censored at the date of the last visit. Categorical data were compared using the Fisher's exact test. Haemodynamic and pulmonary function variables were compared by the two-tailed paired t-test. Statistical significance was established at $\mathrm{p}<0.05$.

\section{RESULTS}

\section{Patient population}

29 LAM patients with suspected $\mathrm{PH}$ at echocardiography underwent RHC. The estimated systolic PAP at echocardiography significantly correlated with the systolic PAP $(r=0.66$, $\mathrm{p}=0.001)$ and with the mean PAP measured at RHC ( $\mathrm{r}=0.69$, $\mathrm{p}=0.0006$ ). The mean difference between the systolic PAP estimated at echocardiography and the systolic PAP measured at $\mathrm{RHC}$ was $-5.4 \mathrm{mmHg}$ (95\% CI $-13--2 \mathrm{mmHg}$ ). The systolic PAP at echocardiography was overestimated by $\geqslant 10 \mathrm{mmHg}$ when compared with RHC in four cases $(14 \%)$, and was underestimated by $\leqslant 10 \mathrm{mmHg}$ in nine cases $(31 \%)$. The difference between the estimated systolic PAP at echocardiography and the measured systolic PAP at RHC was mainly $>10 \mathrm{mmHg}$ in patients with a mean PAP $<25 \mathrm{mmHg}$ (fig. 1).

Nine patients had mean PAP between $20 \mathrm{mmHg}$ and $24 \mathrm{mmHg}$ and were excluded from the subsequent analysis. Thus, the study population comprised of 20 patients, including 18 with sporadic LAM and two with LAM associated with tuberous sclerosis complex; all were female, with a mean age of $49 \pm 12$ yrs and not reported previously [7, 16]. In total, 270 LAM patients were included in the GERM “ $\mathrm{O}^{\prime \prime} \mathrm{P}$ registry $(n=222)$ or followed in the Milan referral centre $(n=48)$ during the study period; therefore, it was estimated that $\mathrm{PH}$ patients represented a minimum of $7 \%$ of LAM patients. The reasons for RHC were evaluation for transplantation $(n=9)$ and/or suspicion of PH based on systematic echocardiography $(n=11)$.

The baseline clinical data are reported in table 1 . The diagnosis of LAM was definitive in 19 patients, and probable in one nonsmoker with characteristic chest imaging, obstructive ventilatory defect, and compatible medical history. A pattern characteristic of LAM [6] was present on HRCT of the chest in all patients. The diagnosis was confirmed by video-assisted thoracoscopic lung biopsy in 13 cases (65\%). 15 patients were ex-smokers, with a median of 10 pack-yrs. One patient had a history of splenectomy and another had taken anorexigens. One patient had undergone unilateral nephrectomy for angiomyolipoma. When compared with LAM patients without $\mathrm{PH}$, patients with LAM and $\mathrm{PH}$ had more severe dyspnoea and presented more frequently with right heart failure or haemoptysis.

LAM was treated as follows: inhaled bronchodilators, $75 \%$ of patients; progesterone derivatives and/or anti-oestrogen therapy, $45 \%$; doxycycline, 30\%; sirolimus, $25 \%$.

\section{Clinical and functional evaluation}

The mean time interval between LAM diagnosis and the first RHC demonstrating PH was 9.2 \pm 9.8 yrs (range $0-36$ yrs), and the mean time period between first respiratory symptoms and $\mathrm{PH}$ was $10.4 \pm 7.5 \mathrm{yrs}$ (range 3.0-22.1 yrs). NYHA functional class was III or IV in $95 \%$ of these patients.

Echocardiography revealed dilated right heart cardiac cavities in seven $(35 \%)$ out of 20 patients. The mean value of systolic PAP estimated at echocardiography was $56 \pm 18 \mathrm{mmHg}$ (range 40-108). Mild pericardial effusion was reported in one patient. B-type natriuretic peptide (BNP) level was normal in all of the seven patients tested. Haemoglobin was $>160 \mathrm{~g} \cdot \mathrm{L}^{-1}$ in two patients $(10 \%)$.

The 6-min walking distance (6MWD) was $340 \pm 84 \mathrm{~m}$, with mean desaturation of $10 \pm 8 \%$. The median Borg index value of dyspnoea at the end of the $6 \mathrm{MWT}$, available in 11 patients, was 4 (range, 3-6). Table 2 presents the pulmonary function test results. Obstructive ventilatory defect, defined by forced expiratory volume in $1 \mathrm{~s}$ (FEV1): forced vital capacity (FVC) $<70 \%$, was present in $83 \%$ of patients. FEV1 was $<80 \%$ predicted value in $84 \%$ of patients, and $<50 \%$ pred value in $63 \%$ of patients. Gas exchange was severely impaired, with a mean single-breath diffusing capacity of the lung for carbon monoxide $(D \mathrm{~L}, \mathrm{CO})$ of $29 \pm 13 \%$ pred value. When compared with LAM patients without $\mathrm{PH}$, patients with LAM and $\mathrm{PH}$ had more severe airflow obstruction, lower diffusion capacity for $\mathrm{CO}$, more severe hypoxaemia and impairment of exercise capacity.

\section{Haemodynamics}

Table 3 reports the results of RHC. Mean PAP was $32 \pm 6 \mathrm{mmHg}$, and pulmonary vascular resistance (PVR) was $376 \pm 184$ dyn $\cdot \mathrm{s} \cdot \mathrm{cm}^{-5}$. None of the eight patients tested were acutely
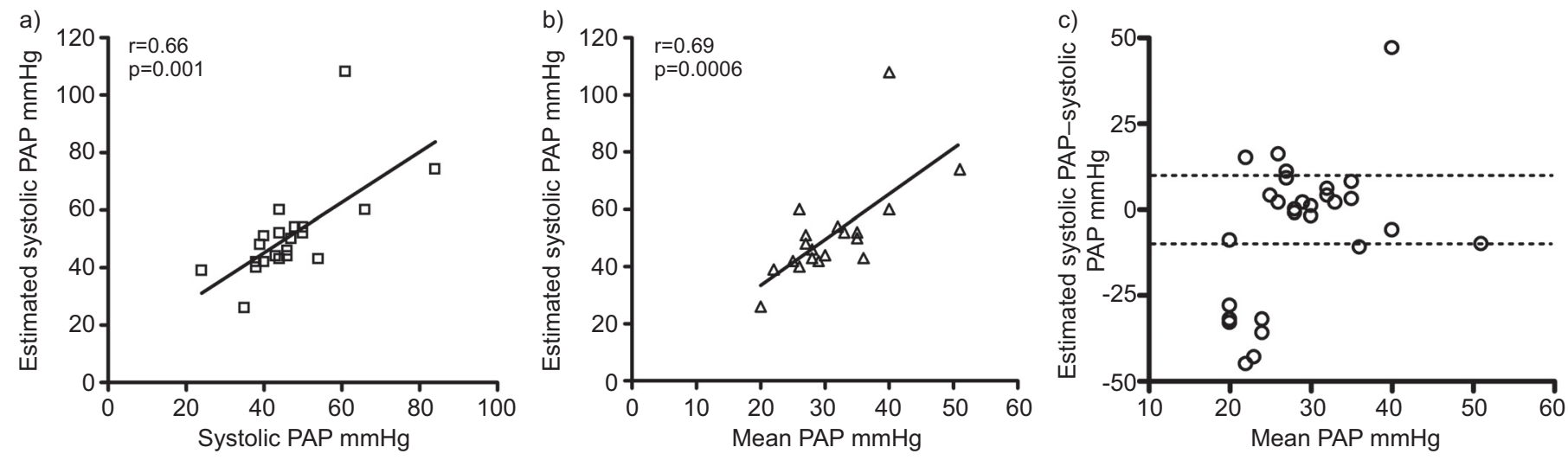

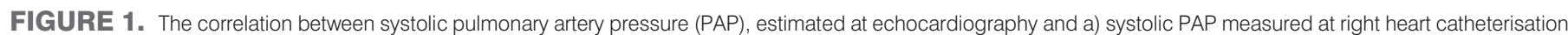

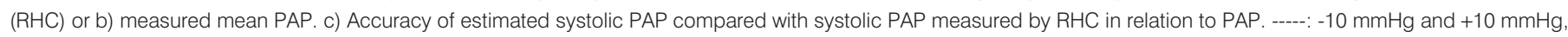
respectively. 


\begin{tabular}{|c|c|c|c|c|}
\hline $\begin{array}{l}\text { TABLE } 1 \\
\text { Variables }\end{array}$ & \multicolumn{4}{|c|}{$\begin{array}{l}\text { Characteristics, clinical manifestations and pulmonary function tests at diagnosis of pre-capillary pulmonary } \\
\text { hypertension }(\mathrm{PH}) \text { in } 20 \text { patients with lymphangioleiomyomatosis (LAM) compared with } 72 \text { patients with LAM } \\
\text { without PH }\end{array}$} \\
\hline \multicolumn{2}{|l|}{ Patients } & 20 & 72 & \\
\hline \multicolumn{2}{|c|}{ Age mean yrs } & $49 \pm 12(33-73)$ & $44 \pm 19(33-73)$ & 0.362 \\
\hline \multicolumn{2}{|l|}{ Smoker } & & & 0.644 \\
\hline \multicolumn{2}{|l|}{ Current } & 0 & 2 & \\
\hline \multicolumn{2}{|l|}{ Ex-smoker } & 5 & 22 & \\
\hline \multicolumn{2}{|c|}{ Never smoked } & 15 & 48 & \\
\hline \multicolumn{2}{|c|}{ LAM diagnosis } & & & 1 \\
\hline \multicolumn{2}{|l|}{ Definite } & 19 & 66 & \\
\hline \multicolumn{2}{|c|}{ History of pneumothorax $\#$} & $8(40)$ & $36(50)$ & 0.460 \\
\hline \multicolumn{2}{|c|}{ History of chylothorax } & $5(25)$ & $13(18)$ & 0.529 \\
\hline \multicolumn{2}{|c|}{ History of chylous ascites } & $2(10)$ & $5(7)$ & 0.643 \\
\hline \multicolumn{2}{|c|}{ Lymphangioleiomyoma } & $3(15)$ & $20(28)$ & 0.382 \\
\hline \multicolumn{2}{|c|}{ Lymph node involvement (pathology) } & $1(5)$ & $6(8)$ & 1 \\
\hline \multicolumn{2}{|l|}{ Dyspnoea } & $20(100)$ & $53(74)$ & 0.009 \\
\hline \multicolumn{2}{|c|}{ NYHA functional class } & & & $<0.001$ \\
\hline \multicolumn{2}{|l|}{ । } & 0 & 11 & \\
\hline \multicolumn{2}{|l|}{$\|$} & 1 & 22 & \\
\hline \multicolumn{2}{|l|}{ III } & 10 & 18 & \\
\hline \multicolumn{2}{|l|}{ IV } & 9 & 4 & \\
\hline
\end{tabular}

Data are presented as $n$, mean \pm SD (range) or $n(\%)$, unless otherwise stated. NYHA: New York Heart Association; NA: not available. ${ }^{*}$ : bilateral in seven out of eight cases; $^{\prime}$ : six other patients had a history of pleural effusion not otherwise specified.

vasoreactive to inhaled NO. Mean PAP was $>35 \mathrm{mmHg}$ in four patients with definite LAM $(20 \%)$, two of whom had normal FEV1, and one with mean PAP of $40 \mathrm{mmHg}$ and FEV1 of $52 \%$ pred had a history of anorexigen intake. Mean PAP was $>40$ $\mathrm{mmHg}$ in one patient $(5 \%)$ who had normal FEV1.

Significant correlations were observed between haemodynamic parameters and pulmonary function (table S1, fig. 2), especially between PVR and FEV1 and DL,CO and the transfer coefficient for the lung for carbon monoxide (KCO), but not with arterial oxygen tension $\left(\mathrm{Pa}_{\mathrm{a}} \mathrm{O}_{2}\right)$ or arterial oxygen saturation measured by pulse oximetry $\left(S_{p}, \mathrm{O} 2\right)$ at the end of the 6MWT. Mean PAP correlated with estimated systolic PAP at echocardiography $(\mathrm{r}=0.583, \mathrm{p}=0.063)$.

\section{Outcome and survival analysis}

$95 \%$ of patients received long-term supplemental nasal oxygen therapy; $30 \%$ received diuretics and $25 \%$ were given oral anticoagulant therapy, for $\mathrm{PH}$.
Six $(30 \%)$ out of the 20 patients received first-line therapy for $\mathrm{PAH}$ with dual endothelin receptor antagonist (bosentan $\mathrm{n}=5$ ) or phosphodiesterase type- 5 inhibitors (sildenafil $n=1$ ) with no concomitant change in supplemental oxygen therapy. No patient was administered prostacyclin derivatives. In this subgroup of six treated patients, no statistically significant difference was observed on NYHA functional class $(p=0.987), 6 \mathrm{MWD}$ $(\mathrm{p}=0.983)$, cardiac index $(\mathrm{p}=0.786), \mathrm{FEV} 1(\mathrm{p}=0.530), \mathrm{Pa}_{\mathrm{a}} \mathrm{O}_{2}$ $(\mathrm{p}=0.179)$ or $\mathrm{Sp}_{\mathrm{O}} \mathrm{O}_{2}(\mathrm{p}=0.880)$ between the evaluation before $\mathrm{PAH}$ therapy and the last evaluation on therapy (fig. 3). Right heart cavities were dilated in three out of six patients, with no change upon PH therapy. Mean PAP decreased significantly in the six treated patients with PAH therapy from $33 \pm 9 \mathrm{mmHg}$ to $24 \pm 10 \mathrm{mmHg}$ (mean difference $9 \mathrm{mmHg}, 95 \%$ CI 5-14; $\mathrm{p}=0.003$ ) after a median of 38 months (interquartile range (IQR) 14.534 months). PVR declined in the six treated patients from $481 \pm 188 \mathrm{dyn} \cdot \mathrm{s} \cdot \mathrm{cm}^{-5}$ to $280 \pm 79 \mathrm{dyn} \cdot \mathrm{s} \cdot \mathrm{cm}^{-5}$ (mean difference 201 dyn.s.cm ${ }^{-5}, 95 \%$ CI 18-384; $\left.\mathrm{p}=0.037\right)$. Overall, an improvement (predefined by NYHA functional class reduction and/or a 


\begin{tabular}{|c|c|c|c|c|}
\hline Variable & Patients & LAM with PH & Control LAM without PH & p-value \\
\hline FVC \% pred & 18 & $76 \pm 28(27-121)$ & $88 \pm 25(30-145)$ & 0.08 \\
\hline \multicolumn{5}{|l|}{ FEV $_{1} \%$ pred } \\
\hline Prebronchodilator & 19 & $42 \pm 24(13-96)$ & $63 \pm 25(16-129)$ & 0.002 \\
\hline Postbronchodilator & 19 & $46 \pm 26(13-96)$ & NA & NA \\
\hline $\mathrm{FEV}_{1} / \mathrm{FVC} \%$ pred & 18 & $47 \pm 15(22-75)$ & $60 \pm 16(24-95)$ & 0.003 \\
\hline TLC \% pred & 20 & $104 \pm 16(77-143)$ & $109 \pm 23(51-169)$ & 0.404 \\
\hline RV \% pred & 20 & $162 \pm 52(63-243)$ & $143 \pm 58(65-309)$ & 0.461 \\
\hline DL,co \% pred & 18 & $29 \pm 13(14-57)$ & $50 \pm 25(15-111)$ & 0.002 \\
\hline Kco \% pred & 13 & $35 \pm 14(19-69)$ & $57 \pm 22(15-93)$ & 0.002 \\
\hline $\mathrm{Pa}, \mathrm{O}_{2}$ at rest $\mathrm{kPa}$ & 17 & $7.4 \pm 1.1(5.5-9.5)$ & $10.1 \pm 1.9(6.7-14.5)$ & $<0.001$ \\
\hline $\mathrm{Pa}, \mathrm{CO}_{2}$ at rest $\mathrm{kPa}$ & 18 & $4.8 \pm 0.5(3.9-5.9)$ & $4.7 \pm 0.6(3.7-6.7)$ & 0.188 \\
\hline 6MWD m & 18 & $340 \pm 84(200-475)$ & $474 \pm 144(110-770)$ & 0.001 \\
\hline $\mathrm{Sp}, \mathrm{O}_{2} \%$ at end of $6 \mathrm{MWT}$ & 18 & $81 \pm 9(57-91)$ & $88 \pm 8(62-99)$ & 0.009 \\
\hline $\mathrm{Sp}, \mathrm{O}_{2} \%$ decrease during $6 \mathrm{MWT}$ & 18 & $-10 \pm 8(-28-0)$ & $-8 \pm 8(-36-2)$ & 0.189 \\
\hline
\end{tabular}

Data are presented as $n$ or mean \pm SD (range) unless otherwise stated. FVC: forced vital capacity; \% pred: \% predicted; FEV1: forced expiratory volume in 1 s; TLC: total lung capacity; RV: residual volume; $\mathrm{DL}, \mathrm{CO}$ : diffusing capacity of the lungs for carbon monoxide; $\mathrm{KCO}$ : transfer coefficient for the lung for carbon monoxide; $\mathrm{Pa}_{\mathrm{a}} \mathrm{O}_{2}$ : arterial oxygen tension; $\mathrm{Pa}_{\mathrm{a}} \mathrm{CO}_{2}$ : arterial carbon dioxide tension; $6 \mathrm{MWD}$ : 6-min walking distance; $\mathrm{Sp}, \mathrm{O}_{2}$ : arterial oxygen saturation measured by pulse oximetry; $\mathrm{NA}$ : not available.

$20 \%$ increase in 6MWD and/or a $20 \%$ decrease in PVR with $20 \%$ diminution of mean PAP) was seen in the five patients who received bosentan, but not in the patient given sildenafil.

In addition, one patient was treated with sirolimus (but no PAH treatment) for LAM progression and had a follow-up evaluation after 10 months of therapy; NYHA functional class had changed from IV to III, 6MWD from $330 \mathrm{~m}\left(\mathrm{Sp}_{\mathrm{p}} \mathrm{O}_{2}\right.$ of $\left.84 \%\right)$ to $350 \mathrm{~m}\left(\mathrm{SpO}_{2}\right.$ of $\left.90 \%\right), \mathrm{FEV}^{1}$ from $27 \%$ to $53 \%$ pred, $\mathrm{FVC}$ from $63 \%$ to $102 \%$, mean PAP from $35 \mathrm{mmHg}$ to $23 \mathrm{mmHg}$, PVR from $168 \mathrm{dyn} \cdot \mathrm{s} \cdot \mathrm{cm}^{-5}$ to $178 \mathrm{dyn} \cdot \mathrm{s} \cdot \mathrm{cm}^{-5}$, and cardiac index from $5.2 \mathrm{~L} \cdot \mathrm{min}^{-1} \cdot \mathrm{m}^{-2}$ to $3.9 \mathrm{~L} \cdot \mathrm{min}^{-1} \cdot \mathrm{m}^{-2}$.

\begin{tabular}{|c|c|c|c|}
\hline \multicolumn{2}{|l|}{ Variable } & \multicolumn{2}{|l|}{ Patients } \\
\hline \multicolumn{2}{|c|}{ Mean PAP, mmHg } & 20 & $32 \pm 6(25-51)$ \\
\hline \multicolumn{2}{|c|}{ Diastolic PAP, mmHg } & 19 & $22 \pm 5(12-30)$ \\
\hline \multicolumn{2}{|c|}{ Systolic PAP, mmHg } & 19 & $48 \pm 11(38-84)$ \\
\hline \multicolumn{2}{|c|}{ Cardiac output, L. $\min ^{-1}$} & 20 & $5.4 \pm 1.9(3.1-9.5)$ \\
\hline \multicolumn{2}{|c|}{ Cardiac index, $\mathrm{L} \cdot \mathrm{min}^{-1} \cdot \mathrm{m}^{-2}$} & 20 & $3.4 \pm 1.1(2.1-5.7)$ \\
\hline \multicolumn{2}{|c|}{ PVR dyn $\cdot \mathbf{s} \cdot \mathrm{cm}^{-5}$} & 20 & $376 \pm 184(118-776)$ \\
\hline \multicolumn{2}{|c|}{ PVR index dyn $\cdot \mathbf{s} \cdot \mathrm{cm}^{-5} \cdot \mathrm{m}^{-2}$} & 20 & $572 \pm 307(190-1433)$ \\
\hline \multicolumn{2}{|c|}{ Right atrial pressure $\mathrm{mmHg}$} & 19 & $7 \pm 3(0-12)$ \\
\hline \multicolumn{2}{|c|}{ Capillary wedge pressure $\mathrm{mmHg}$} & 19 & $10 \pm 3(4-15)$ \\
\hline \multicolumn{2}{|l|}{$\mathrm{Sv}, \mathrm{O}_{2} \%$} & 12 & $69 \pm 7(59-80)$ \\
\hline
\end{tabular}

Data are presented as $\mathrm{n}$ or mean $\pm \mathrm{SD}$ (range). PAP: pulmonary arterial

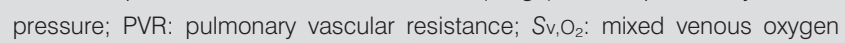
saturation.
Overall, the study subjects were followed for a mean of $2.5 \pm 2.1$ yrs from the diagnosis of PH. No patient was lost to follow-up. At the end of follow-up, one patient had died from cardiac arrest and five patients had undergone single or double lung transplantation (three and two patients, respectively). The overall probability of survival was $94 \%$ at $1 \mathrm{yr}, 94 \%$ at $2 \mathrm{yrs}$, and $78 \%$ at 3 yrs (fig. 4). The transplant-free probability of survival was $87 \%$ at $1 \mathrm{yr}, 78 \%$ at 2 yrs, and $56 \%$ at 3 yrs.

\section{Pathology assessment of explanted lungs}

Pathological assessment of explanted lungs in five patients demonstrated pronounced vascular remodelling, with involvement of the pulmonary arterial walls by characteristic LAM cells (so-called PEComa cells) (table 4, fig. 5). Cells within the remodelled pulmonary arteries were further characterised as LAM/PEComa cells by positive HMB45 immunostaining in $3 / 3$ cases available. As expected, LAM/PEComa cells were also observed along the edges of the lung cysts, bronchioles, and pulmonary lymphatics.

\section{DISCUSSION}

The present study is the first to report the haemodynamic evaluation of LAM patients with pre-capillary $\mathrm{PH}$ confirmed by RHC, the gold standard for PH diagnosis [23].

The main findings were as follows: 1) PH was generally of only mild haemodynamic severity, with mean PAP of $32 \pm 6 \mathrm{mmHg}$ and PVR of $376 \pm 184 \mathrm{dyn} \cdot \mathrm{s} \cdot \mathrm{cm}^{-5}$, and only $20 \%$ of patients had mean PAP >35 mmHg (out-of-proportion PH); 2) $\mathrm{PH}$ was diagnosed after a mean of $9.2 \pm 9.8$ yrs following the LAM diagnosis in patients with mean FEV1 of $46.4 \pm 26 \%$ pred value, chronic hypoxaemia (mean $\mathrm{Pa}_{1} \mathrm{O}_{2}$ of $7.4 \pm 1.1 \mathrm{kPa}$ ), and moderateto-severe exercise intolerance as shown by mean $6 \mathrm{mwd}$ of $340 \pm 84$ m with mean $\mathrm{Sp}, \mathrm{O}_{2}$ of $81.3 \pm 9.3 \%$ at the end of the test; 3 ) patients with $\mathrm{PH}$ had more severe dyspnoea, airflow 

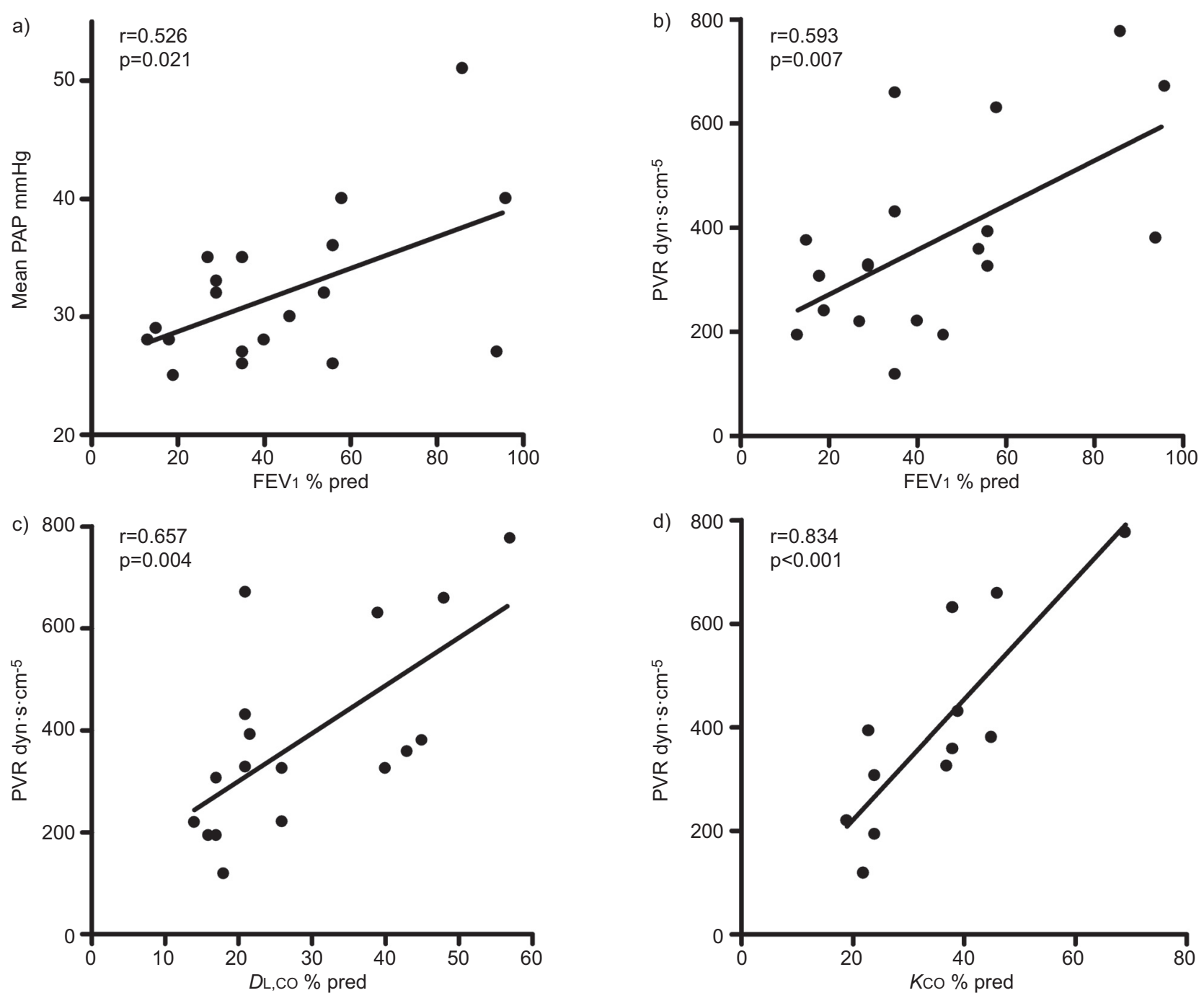

FIGURE 2. Correlation between mean pulmonary arterial pressure (PAP) or pulmonary vascular resistance (PVR) and forced expiratory volume in $1 \mathrm{~s}$ (FEV1), single breath diffusing capacity of the lungs for carbon monoxide $(D L, C O)$, or single breath transfer factor of the lungs for carbon monoxide $(K C O)$. Regression lines are indicated.

$\%$ pred: \% predicted.

obstruction, hypoxaemia, and impairment of exercise capacity than patients with LAM but without $\mathrm{PH}$; 4) haemodynamic parameters correlated with pulmonary function and especially with FEV1, DL,CO, and KCO; 5) significant remodelling of the pulmonary arteries was observed with involvement by HMB45 positive LAM/PEComa cells; 6) the overall probability of survival was $94 \%$ at 2 yrs, and transplant-free survival was $78 \%$ at 2 yrs; 7 ) off-label oral PAH therapy in a subgroup of patients was associated with a significant decrease in mean PAP and PVR without a significant difference in exercise capacity or dyspnoea.

Impairment of pulmonary function in our study population was more severe than in most recent series of LAM patients, who had mean FEV1 of $65 \%$ to $75 \%$ pred at the time of diagnosis [10, 12, $13,30,31]$. Patients with $\mathrm{PH}$ had more airflow obstruction than LAM patients without $\mathrm{PH}$, indicating that $\mathrm{PH}$ generally occurs in subjects with more advanced pulmonary disease. Consistent with this hypothesis, LAM diagnosis preceded PH diagnosis by almost a decade, and five patients (25\%) underwent lung transplantation within 2 yrs after being diagnosed with $\mathrm{PH}$.

However, unexpected correlations were found between lung function and haemodynamic parameters, with greater mean PAP, superior PVR, and lower cardiac index in patients with improved preserved FEV1 and $\mathrm{DL}, \mathrm{CO}$, indicating that $\mathrm{PH}$ may progress independently of parenchymal lung disease. In contrast, systolic or mean PAP correlates inversely with $D \mathrm{~L}, \mathrm{CO}$ in idiopathic pulmonary fibrosis patients, although it correlates poorly with lung volume [32-35]. $\mathrm{Sp}, \mathrm{O}_{2}$ was significantly decreased during exercise, and most LAM and PH patients required long-term oxygen therapy. However, mean PAP did not correlate with $\mathrm{Pa}_{1} \mathrm{O}_{2}$ at rest, consistent with a previous observation that $\mathrm{PH}$ (during exercise) cannot be predicted from resting pulmonary function testing [19]. Although our small sample size prevents firm conclusions, our study indicates that $\mathrm{PH}$ can occur in patients with mild-to-severe lung function impairment and may reflect intrinsic vasculopathy in an 
NYHAFC II NYHAFC III NYHAFC IV
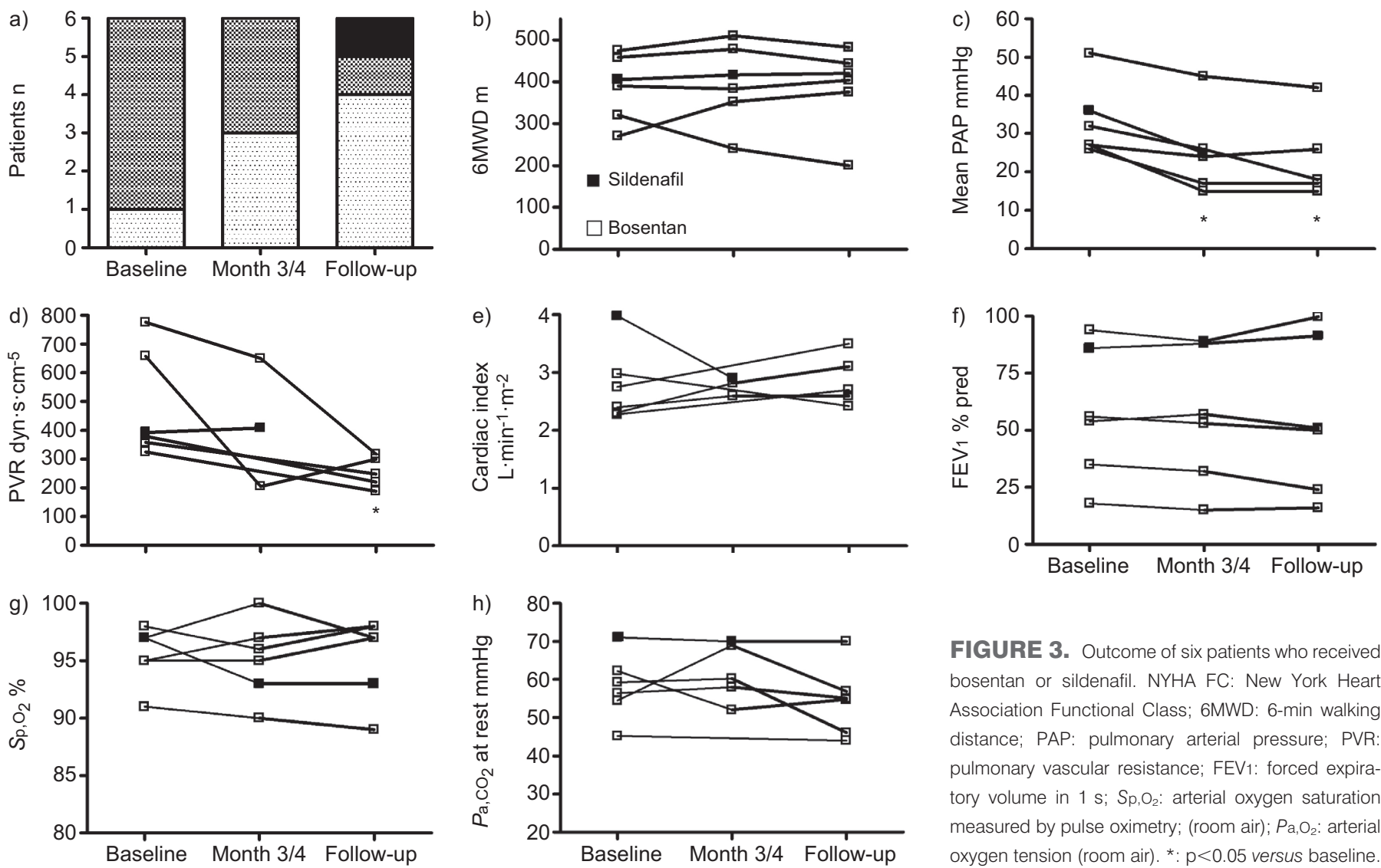

FIGURE 3. Outcome of six patients who received bosentan or sildenafil. NYHA FC: New York Heart Association Functional Class; 6MWD: 6-min walking distance; PAP: pulmonary arterial pressure; PVR: pulmonary vascular resistance; FEV1: forced expiratory volume in $1 \mathrm{~S} ; \mathrm{Sp}_{\mathrm{O}_{2}}$ : arterial oxygen saturation measured by pulse oximetry; (room air); $\mathrm{Pa}_{\mathrm{a}} \mathrm{O}_{2}$ : arterial oxygen tension (room air). ${ }^{*}: p<0.05$ versus baseline.

unknown proportion of patients, as suggested by pathological findings in five patients and earlier descriptions of the involvement of pulmonary arteries by cell proliferation in LAM $[36,37]$. It is conceivable that mTOR activation in LAM may contribute to $\mathrm{PH}$ in patients with LAM [21], as in patients with neurofibromatosis type 1 [38].

The mean PAP in our patients $(32 \pm 6 \mathrm{mmHg})$ was strikingly similar to that reported by REYNAUD-GAUBERT et al. [7] (33 \pm 8 $\mathrm{mmHg}$ ) in nine patients evaluated for lung transplantation, and higher than that observed by HARARI et al. [16] $(26.0 \pm 2.5 \mathrm{mmHg})$ in six patients also evaluated for lung transplantation, but not included in the present series. $\mathrm{PH}$ in the context of chronic parenchymal lung disease is usually mild or moderate (i.e. with mean PAP $<35-40 \mathrm{mmHg}$ ). However, subgroups of patients with chronic obstructive pulmonary disease (COPD) [39-41], idiopathic pulmonary fibrosis [42], or combined pulmonary fibrosis and emphysema syndrome [43] have severe "out-ofproportion" pre-capillary $\mathrm{PH}$, usually defined by mean PAP $>35-40 \mathrm{mmHg}[17,39]$. These subjects are prone to right heart failure and may share similarities with idiopathic PAH [43, 44]. Only $20 \%$ of patients in the present study had mean PAP $>35 \mathrm{mmHg}$ with $5 \%$ disclosing mean PAP >40 mmHg, fulfilling this definition. Interestingly, two of these patients had normal FEV1 with PH and were thus "out-of-proportion". The highest mean PAP recorded in our study was $51 \mathrm{mmHg}$, and $47 \mathrm{mmHg}$ in that of REYNAUD-GAUBERT et al. [7]. The mean haemodynamic profile of LAM patients in the present series was much less severe than that of PAH patients in the national French registry (with a higher PVR index of 1,640 dyn $\cdot \mathrm{s} \cdot \mathrm{cm}^{-5} \cdot \mathrm{m}^{-2}$ and cardiac index of $2.5 \mathrm{~L} \cdot \mathrm{min}^{-1} \cdot \mathrm{m}^{-2}$ ) [22]. It was also less severe than in patients with pre-capillary $\mathrm{PH}$ and pulmonary Langerhans cell histiocytosis [45, 46], combined pulmonary fibrosis and emphysema [43], or sarcoidosis [47], and somewhat comparable to that of $\mathrm{PH}$ associated with idiopathic pulmonary fibrosis [32, 35, 42]. However, although mean PAP was only mildly elevated, some patients with mild lung-function impairment had severe and "out-of-proportion" PH.

The clinical relevance of $\mathrm{PH}$ in patients with LAM is currently unknown. In a study by TAVEIRA-DASILVA et al. [19], peak exercise PAP correlated negatively with $S p, \mathrm{O}_{2}$, indicating that $\mathrm{PH}$ may contribute to exercise-induced hypoxaemia and exercise limitation; increased systolic PAP was observed during low-level exercise corresponding to daily living activities. Predictors of a more severe prognosis could not be evaluated in the present series, because of the small sample size. However, LAM patients with $\mathrm{PH}$ had lower $\mathrm{DL}, \mathrm{CO}$, more severe hypoxaemia, and impaired exercise capacity when compared with LAM patients without $\mathrm{PH}$, suggesting that a low diffusion capacity in LAM should prompt to perform an echocardiography. A significant proportion of our PH and LAM patients died or underwent lung transplantation within 2 yrs of PH diagnosis. Although no formal survival comparison was made to a group of LAM patients without $\mathrm{PH}$, the present finding questions whether PH might have prognostic significance in LAM, similar 

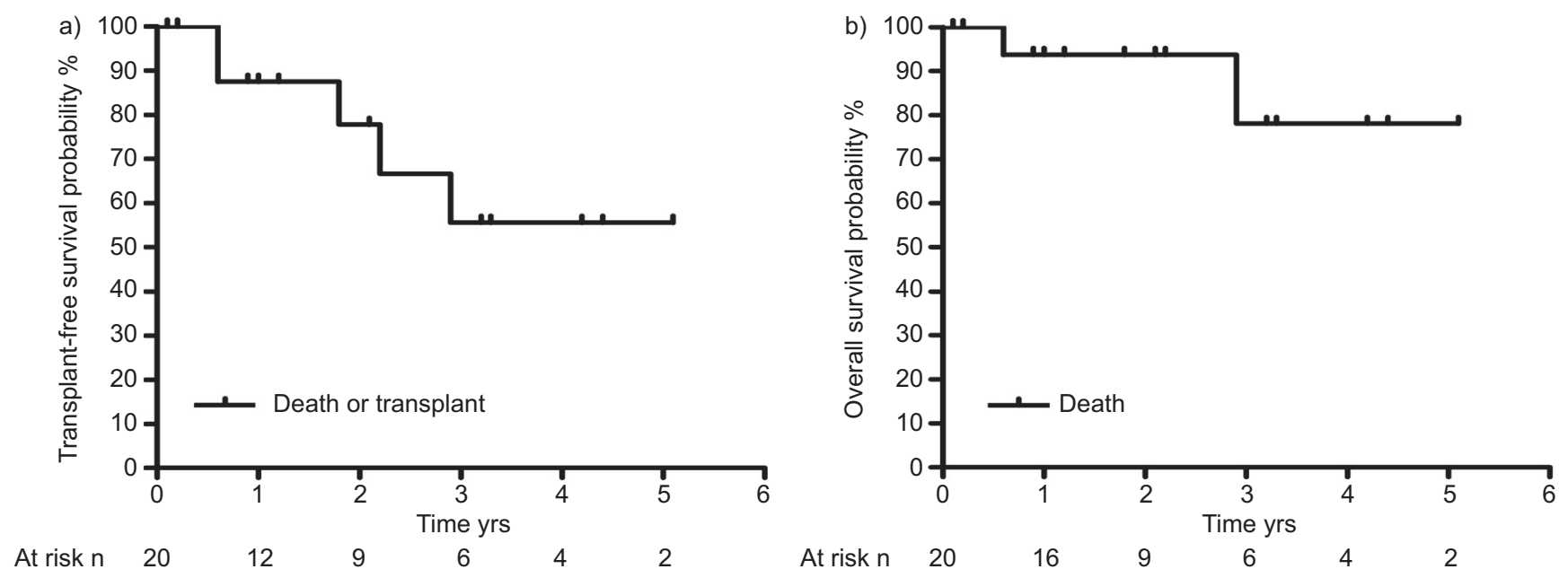

FIGURE 4. Transplant-free and overall survival in patients with lymphangioleiomyomatosis and pulmonary hypertension.

to what has been reported in idiopathic pulmonary fibrosis [42, 48], COPD [49], and combined pulmonary fibrosis and emphysema [50, 51]. The 10-yr survival rate of patients with LAM has been reported to $71 \%, 79 \%$, and $91 \%$ from the time of diagnosis in large series [10,11,52]. Thus, the potential impact of $\mathrm{PH}$ on long-term survival in LAM deserves further analysis in prospective studies.
The potential benefit of PAH-specific therapy is not known in $\mathrm{PH}$ patients with associated pulmonary parenchymal disorders, as these drugs have not been approved in this setting. It is unlikely that the rare occurrence of PH in LAM (an "orphan" disease) will be investigated in a dedicated clinical trial. A minority of patients in the present series were treated off-label on an individual basis, providing some interesting preliminary
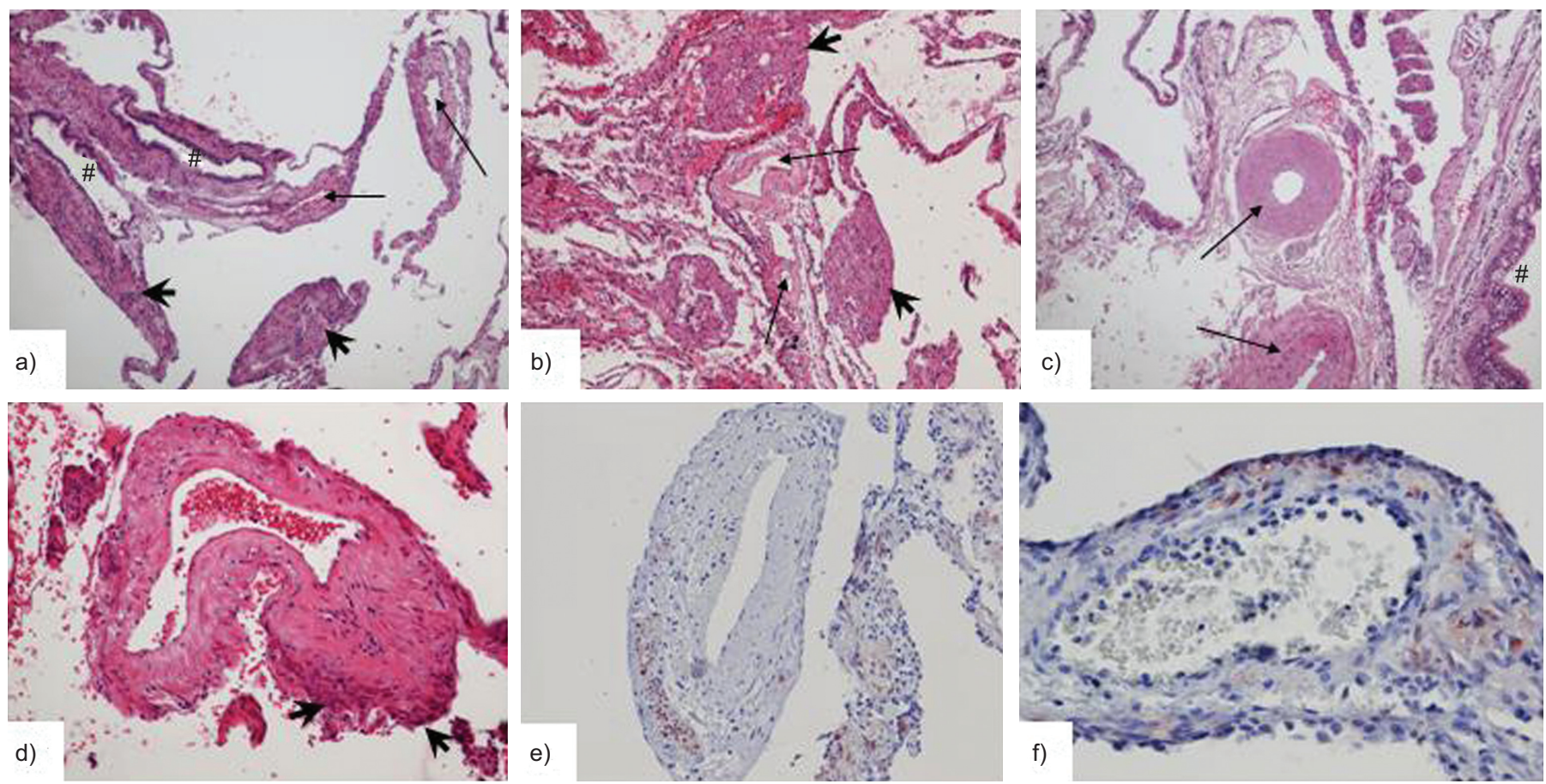

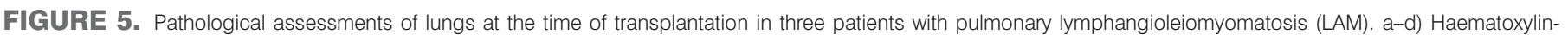

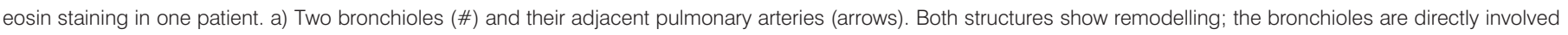

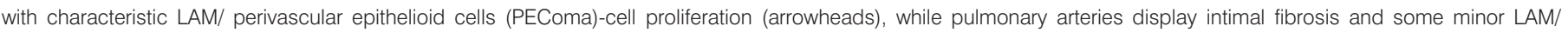

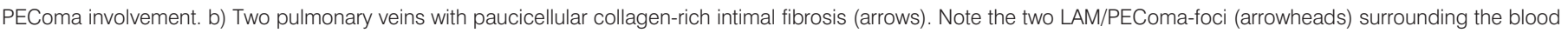

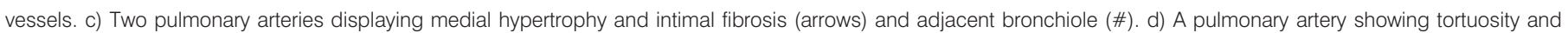

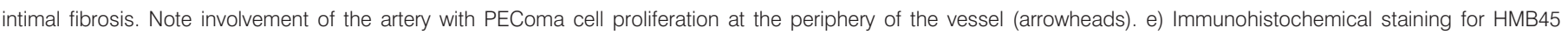

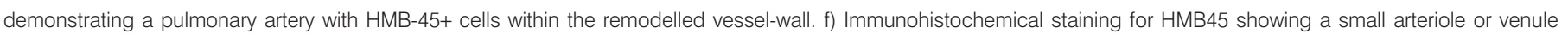
presenting muscularisation and involvement of HMB-45+ LAM cells. 


\begin{tabular}{|c|c|c|c|c|c|c|}
\hline TABLE 4 & $\begin{array}{l}\text { Semiquantitative ass } \\
\text { the diseased lungs }\end{array}$ & $\begin{array}{l}\text { ssment of lymph } \\
\text { f five transplante }\end{array}$ & $\begin{array}{l}\text { gioleiomyomatosis } \\
\text { oatients }\end{array}$ & lascular e & cells (LC) & distribution in \\
\hline Patient & LC along cyst edges & $\begin{array}{c}\text { LC along alveolar } \\
\text { walls }\end{array}$ & $\begin{array}{l}\text { LC along pulmonary } \\
\text { arteries/veins }\end{array}$ & $\begin{array}{l}\text { LC along } \\
\text { lymphatics }\end{array}$ & $\begin{array}{l}\text { LC along } \\
\text { bronchioles }\end{array}$ & HMB45+LC \\
\hline 1 & +r+ & ++ & + & + & + & ++ \\
\hline 2 & ++ & ++ & + & + & + & + \\
\hline 3 & H+ & + & ++ & ++ & ++ & ++ \\
\hline 4 & +H & + & ++ & + & + & UA \\
\hline 5 & n+ & + & n+ & +r+ & +r+ & UA \\
\hline
\end{tabular}

HMB-45 staining was available in three patients and unavailable (UA) in two patients. +: mild; ++: moderate; +++: prominent.

information on the efficacy and safety of PAH therapy in this condition. PAH treatment with bosentan or sildenafil was well tolerated, especially since gas exchange was not significantly impaired as has been observed in some COPD and $\mathrm{PH}$ patients [53]. Although involvement of pulmonary veinules was observed pathologically, pulmonary oedema was not observed at initiation of $\mathrm{PH}$ therapy. Haemodynamics improved significantly with a $28 \%$ decrease in mean PAP and a $42 \%$ reduction of PVR, but no significant effect of therapy was apparent on dyspnoea or exercise capacity (although such analysis was underpowered). Sirolimus, which has proven beneficial in lung function and clinically-relevant parameters [5], should be considered in LAM patients with progressive disease. The present study did not allow us to evaluate whether sirolimus may also contribute to improvement in $\mathrm{PH}$ patients with LAM. Nasal oxygen supplementation should be considered whenever appropriate [6]. Younger LAM patients should be evaluated early for lung transplantation, which remains the issue in advanced disease [6-9].

This study sheds light on the utility of non-invasive methods screening for PH in LAM patients. No patients tested in the present series had elevated serum BNP levels, and only $35 \%$ had dilated right heart cavities on echocardiography. All patients with mean PAP $>25 \mathrm{mmHg}$ at RHC had estimated systolic PAP of $\geqslant 40 \mathrm{mmHg}$ based on systolic regurgitation of the tricuspid valve. Conversely, patients who eventually manifested mean PAP between $20 \mathrm{mmHg}$ and $25 \mathrm{mmHg}$ had estimated systolic PAP $\leqslant 40 \mathrm{mmHg}$ on echocardiography. Although this study was not designed to evaluate the diagnostic value of echocardiography, we suggest that LAM patients with estimated systolic PAP $\geqslant 40 \mathrm{mmHg}$ on echocardiography undergo RHC. It is known that echocardiography lacks specificity and accuracy in patients with advanced lung disease, including emphysema [54] and idiopathic pulmonary fibrosis $[55,56]$. No patients in the present study had post-capillary $\mathrm{PH}$. Although the current study was not designed to evaluate the prevalence of $\mathrm{PH}$, a conservative $7 \%$ was estimated for $\mathrm{PH}$ prevalence in LAM patients, consistent with a previous similar assessment based on echocardiography [19].

Our investigation has some limitations, especially its observational and uncontrolled design owing to the rarity of this condition. However, LAM cases were prospectively included in the GERM" $\mathrm{O}^{\prime \prime} \mathrm{P}$ registry, and haemodynamic data were collected prospectively in the setting of the French national PH registry. Haemodynamic and pulmonary functions were not evaluated during exercise. As indications for echocardiography and treatment were left to the physicians' discretion, the data presented here are potentially subject to bias and should not be interpreted as proper evaluation of therapeutic efficacy. However, data on haemodynamic parameters and survival were unlikely to be affected by the study design.

In conclusion, $\mathrm{PH}$ may occur in a small subset of LAM patients after a mean of 9 yrs after diagnosis. It can affect LAM patients with mildly to severely-impaired lung function, most of them requiring long-term oxygen therapy. However, mean $\mathrm{PAP}$ and PVR did not correlate with $\mathrm{Pa}_{1} \mathrm{O}_{2}$, indicating that factors other than hypoxia, and especially LAM/PEComa cell vasculopathy, may contribute to $\mathrm{PH}$. Whether $\mathrm{PAH}$-specific therapy may be beneficial in LAM patients with $\mathrm{PH}$ deserves further study.

\section{SUPPORT STATEMENT}

Funding was provided by the Comité national contre les maladies respiratoires (CNMR) and the Seventh Framework Program of the European Commission

\section{STATEMENT OF INTEREST}

A statement of interest for V. Cottin, M. Humbert, X. Jaïs, G. Simonneau and J-F Cordier can be found at www.erj.ersjournals. $\mathrm{com} / \mathrm{site} / \mathrm{misc} /$ statements.xhtml

\section{ACKNOWLEDGEMENTS}

The authors are indebted to all the patients who participated in this study, the French Association of Patients with Lymphangioleiomyomatosis (F-LAM), and all physicians who took care of these patients. The authors would also like to thank C. Silarakis for bibliographic assistance, O. Da Silva for editing this manuscript, and F. ThivoletBéjui (Lyon, France), F. Calabrese (Padova, Italy), M.J. Payan (Marseille, France) and C. Danel (Paris, France) who contributed the pathology slides. Other collaborators who were also involved in the study included B. Crestani (Paris, France), S. Günther (Clamart, France), S. Hirschi (Strasbourg, France), and C. Khouatra (Lyon, France).

The affiliations for the authors are as follows: V Cottin, S. Zeghmar and J-F Cordier: Hospices Civils de Lyon, Hôpital Louis Pradel, Service de pneumologie - Centre de référence national des maladies pulmonaires rares et Centre de compétences de l'hypertension artérielle pulmonaire, Lyon, and Université de Lyon, Université Lyon I, INRA, UMR754 INRAVetagrosup EPHE IFR 128, Lyon, France. S. Harari: Unita operativa di pneumologia e terapia semi-intensiva respiratoria, Servizio di fisiopatologia respiratoria ed emodinamica polmonare, Ospedale San Giuseppe, Milano, Italy. M. Humbert, X. Jaïs and Gérald Simonneau: Université Paris-Sud, Faculté de médecine, Le Kremlin Bicêtre, Service de 
pneumologie - Centre de référence de l'hypertension pulmonaire sévère, Hôpital Bicêtre, AP-HP and INSERM UMR 999, Clamart, France. H. Mal and C. Taillé: Hôpital Bichat, Centre de compétences des maladies pulmonaires rares, Paris, France. P. Dorfmüller: Service d'Anatomie et de cytologie pathologiques, Hôpital Marie Lannelongue, INSERM UMR 999, Le Plessis Robinson, France. M. Reynaud-Gaubert: AP-HM, CHU Nord, Service de pneumologie, Centre de compétences des maladies pulmonaires rares et Centre de compétences de l'hypertension artérielle pulmonaire; and URMITE CNRS- UMR 6236, Université Aix-Marseille II, Marseille, France. G. Prevot: Hôpital Larrey, Centre de compétences de l'hypertension artérielle pulmonaire, Toulouse, France. J. Lacronique: Service de pneumologie, Hôpital Cochin, AP-HP , Université Paris Descartes, Sorbonne Paris Cité, Paris, France. R. Lazor: Hospices Civils de Lyon, Hôpital Louis Pradel, Service de pneumologie - Centre de référence national des maladies pulmonaires rares et Centre de compétences de l'hypertension artérielle pulmonaire, Université de Lyon, Université Lyon I, INRA, UMR754 INRA-Vetagrosup EPHE IFR 128, Lyon, France, and Consultation des pneumopathies interstitielles et maladies pulmonaires rares, Service de pneumologie, Centre hospitalier universitaire vaudois, Lausanne, Switzerland.

\section{REFERENCES}

1 Johnson SR. Lymphangioleiomyomatosis. Eur Respir J 2006; 27: 1056-1065.

2 McCormack FX. Lymphangioleiomyomatosis: a clinical update. Chest 2008; 133: 507-516.

3 Harari S, Torre O, Moss J. Lymphangioleiomyomatosis: what do we know and what are we looking for? Eur Respir Rev 2011; 20: 34-44.

4 Cottin V, Archer F, Leroux C, et al. Milestones in lymphangioleiomyomatosis research. Eur Respir Rev 2011; 20: 3-6.

5 McCormack FX, Inoue Y, Moss J, et al. Efficacy and safety of sirolimus in lymphangioleiomyomatosis. N Engl J Med 2011; 364: 1595-1606.

6 Johnson SR, Cordier JF, Lazor R, et al. European Respiratory society guidelines for the diagnosis and management of lymphangioleiomyomatosis. Eur Respir J 2010; 35: 14-26.

7 Reynaud-Gaubert M, Mornex JF, Mal H, et al. Lung transplantation for lymphangioleiomyomatosis: the French experience. Transplantation 2008; 86: 515-520.

8 Benden C, Rea F, Behr J, et al. Lung transplantation for lymphangioleiomyomatosis: the European experience. $J$ Heart Lung Transplant 2009; 28: 1-7.

9 Boehler A, Speich R, Russi EW, et al. Lung transplantation for lymphangioleiomyomatosis. N Engl J Med 1996; 335: 1275-1280.

10 Urban T, Lazor R, Lacronique J, et al. Pulmonary lymphangioleiomyomatosis. A study of 69 patients. Groupe d'etudes et de recherche sur les maladies "orphelines" pulmonaires (GERM" $\mathrm{O}$ "P). Medicine (Baltimore) 1999; 78: 321-337.

11 Johnson SR, Whale CI, Hubbard RB, et al. Survival and disease progression in UK patients with lymphangioleiomyomatosis. Thorax 2004; 59: 800-803.

12 Lazor R, Valeyre D, Lacronique J, et al. Low initial KCO predicts rapid FEV1 decline in pulmonary lymphangioleiomyomatosis. Respir Med 2004; 98: 536-541.

13 Taveira-DaSilva AM, Stylianou MP, Hedin CJ, et al. Decline in lung function in patients with lymphangioleiomyomatosis treated with or without progesterone. Chest 2004; 126: 1867-1874.

14 Taveira-DaSilva AM, Hedin C, Stylianou MP, et al. Reversible airflow obstruction, proliferation of abnormal smooth muscle cells, and impairment of gas exchange as predictors of outcome in lymphangioleiomyomatosis. Am J Respir Crit Care Med 2001; 164: 1072-1076.

15 Johnson SR, Tattersfield AE. Decline in lung function in lymphangioleiomyomatosis: relation to menopause and progesterone treatment. Am J Respir Crit Care Med 1999; 160: 628-633.
16 Harari S, Simonneau G, De Juli E, et al. Prognostic value of pulmonary hypertension in patients with chronic interstitial lung disease referred for lung or heart-lung transplantation. J Heart Lung Transplant 1997; 16: 460-463.

17 Simonneau G, Robbins IM, Beghetti M, et al. Updated clinical classification of pulmonary hypertension. J Am Coll Cardiol 2009; 54: S43-S54.

18 Tsangaris I, Orfanos S, Bouros D. Pulmonary hypertension and lung diseases: a suggestion for revision of the clinical classification. Eur Respir J 2010; 35: 700-701.

19 Taveira-DaSilva AM, Hathaway OM, Sachdev V, et al. Pulmonary artery pressure in lymphangioleiomyomatosis: an echocardiographic study. Chest 2007; 132: 1573-1578.

20 Goncharova EA, Goncharov DA, Eszterhas A, et al. Tuberin regulates p70 S6 kinase activation and ribosomal protein $\mathrm{S} 6$ phosphorylation. A role for the TSC2 tumor suppressor gene in pulmonary lymphangioleiomyomatosis (LAM). J Biol Chem 2002; 277: 30958-30967.

21 Krymskaya VP, Snow J, Cesarone G, et al. mTOR is required for pulmonary arterial vascular smooth muscle cell proliferation under chronic hypoxia. FASEB J 2011; 25: 1922-1933.

22 Humbert M, Sitbon O, Chaouat A, et al. Pulmonary arterial hypertension in France: results from a national registry. Am J Respir Crit Care Med 2006; 173: 1023-1030.

23 Galiè N, Hoeper MM, Humbert M, et al. Guidelines for the diagnosis and treatment of pulmonary hypertension. Eur Respir J 2009; 34: 1219-1263.

24 Sitbon $\mathrm{O}$, Humbert $\mathrm{M}$, Jais $\mathrm{X}$, et al. Long-term response to calcium channel blockers in idiopathic pulmonary arterial hypertension. Circulation 2005; 111: 3105-3111.

25 Macintyre N, Crapo RO, Viegi G, et al. Standardisation of the single-breath determination of carbon monoxide uptake in the lung. Eur Respir J 2005; 26: 720-735.

26 Miller MR, Hankinson J, Brusasco V, et al. Standardisation of spirometry. Eur Respir J 2005; 26: 319-338.

27 Wanger J, Clausen JL, Coates A, et al. Standardisation of the measurement of lung volumes. Eur Respir J 2005; 26: 511-522.

28 Quanjer PH, Tammeling GJ, Cotes JE, et al. Lung volumes and forced ventilatory flows. Report working party standardization of lung function tests, European Community for Steel and Coal. Official statement of the European Respiratory Society. Eur Respir J 1993; 6: Suppl. 16, 5-40.

29 ATS statement: guidelines for the six-minute walk test. Am J Respir Crit Care Med 2002; 166: 111-117.

30 Johnson SR, Tattersfield AE. Clinical experience of lymphangioleiomyomatosis in the UK. Thorax 2000; 55: 1052-1057.

31 Ryu JH, Moss J, Beck GJ, et al. The NHLBI lymphangioleiomyomatosis registry: characteristics of 230 patients at enrollment. Am J Respir Crit Care Med 2006; 173: 105-111.

32 Nathan SD, Shlobin OA, Ahmad S, et al. Pulmonary hypertension and pulmonary function testing in idiopathic pulmonary fibrosis. Chest 2007; 131: 657-663.

33 Hamada K, Nagai S, Tanaka S, et al. Significance of pulmonary arterial pressure and diffusion capacity of the lung as prognosticator in patients with idiopathic pulmonary fibrosis. Chest 2007; 131: 650-656.

34 Nadrous HF, Pellikka PA, Krowka MJ, et al. Pulmonary hypertension in patients with idiopathic pulmonary fibrosis. Chest 2005; 128: 2393-2399.

35 Shorr AF, Wainright JL, Cors CS, et al. Pulmonary hypertension in patients with pulmonary fibrosis awaiting lung transplant. Eur Respir J 2007; 30: 715-721.

36 Corrin B, Liebow AA, Friedman PJ. Pulmonary lymphangiomyomatosis. A review. Am J Pathol 1975; 79: 348-382.

37 Carrington CB, Cugell DW, Gaensler EA, et al. Lymphangioleiomyomatosis. Physiologic-pathologic-radiologic correlations. Am Rev Respir Dis 1977; 116: 977-995. 
38 Montani D, Coulet F, Girerd B, et al. Pulmonary hypertension in patients with neurofibromatosis type I. Medicine (Baltimore) 2011; 90 : 201-211.

39 Chaouat A, Bugnet AS, Kadaoui N, et al. Severe pulmonary hypertension and chronic obstructive pulmonary disease. Am J Respir Crit Care Med 2005; 172: 189-194.

40 Thabut G, Dauriat G, Stern JB, et al. Pulmonary hemodynamics in advanced copd candidates for lung volume reduction surgery or lung transplantation. Chest 2005; 127: 1531-1536.

41 Weitzenblum E, Delcroix M. Treatment of pulmonary hypertension in chronic obstructive pulmonary disease. Eur Respir Mon 2006; 38: 313-324.

42 Lettieri CJ, Nathan SD, Barnett SD, et al. Prevalence and outcomes of pulmonary arterial hypertension in advanced idiopathic pulmonary fibrosis. Chest 2006; 129: 746-752.

43 Cottin V, Le Pavec J, Prévot G, et al. Pulmonary hypertension in patients with combined pulmonary fibrosis and emphysema syndrome. Eur Respir J 2010; 35: 105-111.

44 Chaouat A, Naeije R, Weitzenblum E. Pulmonary hypertension in COPD. Eur Respir J 2008; 32: 1371-1385.

45 Fartoukh M, Humbert M, Capron F, et al. Severe pulmonary hypertension in histiocytosis X. Am J Respir Crit Care Med 2000; 161: 216-223.

46 Kiakouama L, Cottin V, Etienne-Mastroïanni B, et al. Severe pulmonary hypertension in histiocytosis $\mathrm{X}$ : long-term improvement with bosentan. Eur Respir J 2010; 36: 202-204.

47 Nunes H, Humbert M, Capron F, et al. Pulmonary hypertension associated with sarcoidosis: mechanisms, haemodynamics and prognosis. Thorax 2006; 61: 68-74.
48 Patel NM, Lederer DJ, Borczuk AC, et al. Pulmonary hypertension in idiopathic pulmonary fibrosis. Chest 2007; 132: 998-1006.

49 Oswald-Mammosser M, Weitzenblum E, Quoix E, et al. Prognostic factors in COPD patients receiving long-term oxygen therapy. Importance of pulmonary artery pressure. Chest 1995; 107: 1193-1198.

50 Cottin V, Nunes H, Brillet PY, et al. Combined pulmonary fibrosis and emphysema: a distinct underrecognised entity. Eur Respir J 2005; 26: 586-593.

51 Mejia M, Carrillo G, Rojas-Serrano J, et al. Idiopathic pulmonary fibrosis and emphysema: decreased survival associated with severe pulmonary arterial hypertension. Chest 2009; 136: 10-15.

52 Matsui K, Beasley MB, Nelson WK, et al. Prognostic significance of pulmonary lymphangioleiomyomatosis histologic score. Am J Surg Pathol 2001; 25: 479-484.

53 Blanco I, Gimeno E, Munoz PA, et al. Hemodynamic and gas exchange effects of sildenafil in patients with chronic obstructive pulmonary disease and pulmonary hypertension. Am J Respir Crit Care Med 2010; 181: 270-278.

54 Fisher MR, Criner GJ, Fishman AP, et al. Estimating pulmonary artery pressures by echocardiography in patients with emphysema. Eur Respir J 2007; 30: 914-921.

55 Nathan SD, Shlobin OA, Barnett SD, et al. Right ventricular systolic pressure by echocardiography as a predictor of pulmonary hypertension in idiopathic pulmonary fibrosis. Respir Med 2008; 102: 1305-1310.

56 Arcasoy SM, Christie JD, Ferrari VA, et al. Echocardiographic assessment of pulmonary hypertension in patients with advanced lung disease. Am J Respir Crit Care Med 2003; 167: 735-740. 